\title{
Serological and molecular investigations of brucellosis in dairy cows at certain areas of Al-Sulaymaniyah governorate, Iraq
}

\author{
K.M. Ridhae ${ }^{1}\left[\right.$ and S.A. Hussein ${ }^{2}(\mathbb{0}$ \\ ${ }^{1}$ Directorate of Veterinary Hospital, ${ }^{2}$ Department of Basic Sciences, College of Dentistry, University of Sulaimani, \\ Al-Sulaimaniyah, Iraq
}

\begin{tabular}{l} 
Article information \\
\hline Article history: \\
Received July 18, 2020 \\
Accepted April 16, 2021 \\
Available online October 1, 2021 \\
\hline Keywords: \\
Brucellosis \\
iELISA \\
PCR \\
RBPT \\
\\
\hline Correspondence: \\
S.A. Hussein \\
suha.hussein@ univsul.edu.iq
\end{tabular}

\begin{abstract}
This study aimed to detect Brucella antibodies in the sera of dairy cows and to identify Brucella species in the milk of seropositive cows. A total of 100 sera and 100 milk samples were collected from two 50-cows groups (group 1 with and group 2 without a history of reproductive problems and/or decreased milk production). Rose Bengal plate test and indirect ELISA were used to explore Brucella antibodies in the serum samples and thereafter milk samples of seropositive cows were undergone PCR analysis using Brucella genus specific primers and 3 pairs of species specific primers for identification of $B$. abortus, B. melitensis and B. suis. The RBPT showed 22 cows were carriers for the Brucella antibodies, 18 in group 1 and 4 in group 2 whereas the iELISA showed only 10 cows out of these 22 cows were positive, 9 in group 1 and only 1 cow in group 2 . The PCR assay, which was performed on milk samples of the RBPT positive cows, revealed 18 samples were positive for the Brucella genus and the Brucella abortus species and were negative for Brucella melitensis and Brucella suis species. As a conclusion, the results of this study showed that brucellosis has been encountered in cows with or without a history of reproductive problems, and the RBPT followed by PCR assay for milk samples of the seropositive cows could provide more specific detection than performing either test alone and could be more useful for rapid screening of brucellosis in dairy cows.
\end{abstract}

DOI: 10.33899/ijvs.2021.127688.1520, (CAuthors, 2021, College of Veterinary Medicine, University of Mosul.

This is an open access article under the CC BY 4.0 license (http://creativecommons.org/licenses/by/4.0/).

\section{Introduction}

Brucellosis is an animal disease with a significant zoonotic potential worldwide (1) and in Erbil (2). It causes considerable economic losses in the field of animal production due to abortion or the full-term birth of dead or weak neonates and due to the marked reduce in the levels of fertility and milk production (3). It is caused by gramnegative, non-motile, coccobacilli bacterial of the genus Brucella which includes B. abortus, B. melitensis, B. suis, B. canis, B. ovis, and B. neotomae (4). In addition, 2 more species have been reported in marine mammals including $B$. cetaceae in dolphins and whales and $B$. pinnipediae in seals (5). There are various serological tests used as screening tests for detection of brucellosis such as Rose Bengal Plate Test (RBPT), Standard Tube Agglutination Test (STAT), Enzyme Linked Immuno Sorbent Assay (ELISA) and several other serological tests (6). However, because of limitations of using these conventional serological tests for confirmatory detection of the fastidious Brucella pathogens, nucleic acid amplification techniques such as the polymerase chain reaction (PCR) offers a reliable diagnostic tool for the detection of brucellosis. This technique is characterized by high sensitivity and specificity, promptness and safety (7). Few studies were conducted on brucellosis in our region (AlSulaimaniyah Governorate, Iraq), therefore, the current study may represent a new addition to the information on 
brucellosis in this region through the detection of brucellosis in dairy cows using sero-diagnostic tests (RBPT and iELISA) and identification of Brucella species in the milk of sero-positive cases using conventional PCR.

\section{Materials and methods}

\section{Study areas and animals}

Blood and milk samples were collected during the period extended from November 2014 to May 2015 from two groups of local breed dairy cows: group one included $50,3-7$ years old cows with a history of abortion, stillbirth, reduced milk production and/or reproductive problems from certain regions surrounding Al-Sulaimaniyah city including Garmk, Saidsadiq, Bngrd, Kalar and sharazur and group two included 50, 2-5 years old cows without such a history in 4 dairy farms in Tanjaro region. Cows of both groups were non-vaccinated against brucellosis.

\section{Blood sampling and serum preparation}

After disinfecting by $70 \%$ ethyl alcohol, $8-10 \mathrm{ml}$ blood were collected from the jugular vein and poured slowly into a sterile test tube. The samples were coded and transferred to the laboratory with minimal delay in an insulated ice box. Sera of these blood samples were prepared after centrifugation at $2500 \mathrm{rpm}$ for $10 \mathrm{~min}$ and 1-2 ml of each serum sample were collected by a disposable pipette, dispensed into two sterile Eppendorf tubes and stored at $-20{ }^{\circ} \mathrm{C}$ for subsequent testing by the Rose Bengal Plate test and iELISA.

\section{Milk sampling}

Twenty-two milk samples were taken from the seropositive cows as recommended by the OIE Manual (8). Briefly: The whole udder was washed, dried, and the teats' tips were disinfected with swab of $70 \%$ ethyl alcohol and wiped to dry starting with teats on the far side of the udder. Following that, the milk samples were collected starting from the near side's teats and then moving to the far side's teats after discarding the first one or two milk streams. Approximately 10-20 ml of milk were collected from the 4 quarters of each cow into a labeled, sterile, screw capped vial and transferred to the laboratory by an insulated ice box. In the lab, the milk samples were stored at $-20^{\circ} \mathrm{C}$ in the freezer (Angelantoni, Italy) and subsequently used for DNA extraction.

\section{Serological detection of Brucellosis by the rose bengal plate test}

The Rose Bengal Plate test was performed for all of the 100 serum samples according to the manufacturer's instruction as follows: The serum samples to be tested and the Rose Bengal reagent were left for de-freeze at $18-26^{\circ} \mathrm{C}$ for about 30 minutes; following that, the reactants were mixed by dispensing a $25 \mu 1$ aliquot of each serum sample and a $25 \mu \mathrm{l}$ aliquot of the Rose Bengal Brucella antigen on the kit's plate using a distinct pipette tip for each serum sample. The mixture was thoroughly mixed by inverting and swirling and the results were checked out by naked eyes after 4 minutes. The serum sample was considered positive if a distinctive agglutination was evident (IDEXX, USA).

\section{Serological detection of Brucellosis by the iELISA}

The iELISA test was achieved to detect the IgG in the sera of the cows using a ready to use kit according to the manufacturer's instruction (IDEXX, USA). The reagents, serum samples and positive and negative serum controls were brought to $18-26{ }^{\circ} \mathrm{C}$ before use. The optical density values of the samples and controls were measured using 96-well Microtiter plate ELISA reader equipped with a $450 \mathrm{~nm}$ filter (Biotech Company, USA). The obtained results were recorded, calculated and interpreted according to the manufacturer's instruction.

\section{Genomic DNA extraction from milk samples}

DNA extraction from the milk samples of the RBPT positive cows and from two positive control Brucella strains, B. abortus vaccine strain 19 (Vital, Turkey) and $B$. melitensis vaccine strain Rev.1 (Jovac, Jordan Bioindustries center) was performed using the Geneaid DNA extraction kit according to the manufacturer instructions (Geneaid, South Korea). The obtained DNA extracts were checked out by agarose gel electrophoresis and stored at $-20^{\circ} \mathrm{C}$ until PCR technique use.

\section{Conventional PCR technique}

Four pairs of primers (Accupower ${ }^{\circledR}$ Bioneer, South Korea) were specifically used for DNA amplification (Table 1). The PCR mixture comprised $2 \mu \mathrm{l} 10 \mathrm{X}$ PCR buffer (2.5 U Taq DNA polymerase, $2 \mathrm{mM} \mathrm{MgCl} 2$, dNTPs $(200 \mu \mathrm{M}$ each $)), 10 \mathrm{pmol}(1 \mu \mathrm{l})$ of each of the forward and reserved primers, $10 \mathrm{ng}(4 \mu \mathrm{l})$ of the template DNA and up to $20 \mu \mathrm{l}$ nuclease-free de-ionized water. The amplification was carried out in a thermal cycler throughout an initial denaturation at $95^{\circ} \mathrm{C}$ for $5 \mathrm{~min} ; 35$ thermal cycles of denaturation at $90^{\circ} \mathrm{C}$ for 40 seconds, annealing at $60^{\circ} \mathrm{C}$ for 20 seconds for the genus specific primers and $58^{\circ} \mathrm{C}$ for 30 seconds for the species specific primers, and extension at $72^{\circ} \mathrm{C}$ for 40 seconds; and a final extension at $72^{\circ} \mathrm{C}$ for 7 min. Following that, the PCR products were processed for electrophoresis in $1 \%$ agarose gel stained with Green DNA dyes and visualized by a UV transilluminator at $320 \mathrm{~nm}$.

\section{Statistical analysis}

Statistical analysis of the results was performed using the SPSS software version 19.0 (9), the Chi square test for independence (10) and Z-test for proportions (11). P values less than 0.05 were considered significant. 
Table 1: List of primer pairs used in the PCR assay

\begin{tabular}{|c|c|c|c|c|c|}
\hline Primers & Gen name & Target gene & Sequence $5^{\prime}-3^{\prime}$ & size (bp) & References \\
\hline Brucella genus (general) & $\begin{array}{l}\text { B4 (F) } \\
\text { B5 (R) }\end{array}$ & BCSP 31 & $\begin{array}{l}\text { TGG-CTC-GGT-TGC-CAA-TAT-CAA } \\
\text { CGC-GCT-TGC-CTT-TCA-GGT-CTG }\end{array}$ & 223 & (12) \\
\hline B. abortus & $\begin{array}{l}\mathrm{F} \\
\mathrm{R} \\
\end{array}$ & IS711 & $\begin{array}{l}\text { CATGCGCTATGTCTGGTTAC } \\
\text { GGCTTTTCTATCACGGTATTC }\end{array}$ & 113 & (13) \\
\hline B. melitensis & $\begin{array}{l}\mathrm{F} \\
\mathrm{R}\end{array}$ & IS711 & $\begin{array}{c}\text { CATGCGCTATGTCTGGTTAC } \\
\text { AGTGTTTCGGCTCAGAATAATC }\end{array}$ & 252 & (13) \\
\hline B. suis & $\begin{array}{l}\mathrm{F} \\
\mathrm{R}\end{array}$ & IS711 & $\begin{array}{l}\text { GCG-CGG-TTT-TCT-GAA-GGT-TCA-GG } \\
\text { TGC-CGA-TCA-CTT-AAG-GGC-CTT-CAT }\end{array}$ & 285 & (14) \\
\hline
\end{tabular}

\section{Results}

Serological detection of Brucellosis by RBPT and iELISA

The results of the current study showed that the RBPT was significantly $(\mathrm{P}<0.05)$ different compared to the iELISA in serological detection of brucellosis. In group one (cows with a history of abortion, reproductive problems and/or decreased milk production), the RBPT showed that 18 out of 50 cows $36 \%$ were carriers for the Brucella antibodies in comparison with the iELISA test which revealed only 9 positive cases $\% 18$. In group two (only 4 positive cases $8 \%$ out of 50 cows were evident by the RBPT compared to only one positive case $2 \%$ was evident by the iELISA (Table 2, Figures 1 and 2).

Table 2: Serological detection of brucellosis by the RBPT and iELISA

\begin{tabular}{lccc}
\hline Animal groups & $\begin{array}{c}\text { No. of } \\
\text { samples }\end{array}$ & $\begin{array}{c}\text { RBPT } \\
\text { positive }\end{array}$ & $\begin{array}{c}\text { ELISA } \\
\text { positive }\end{array}$ \\
\hline Group one cows $*$ & 50 & $18(36 \%)^{\mathrm{a}}$ & $9(18 \%)^{\mathrm{b}}$ \\
Group two cows $* *^{\mathrm{a}}$ & 50 & $4(8 \%)^{\mathrm{a}}$ & $1(2 \%)^{\mathrm{a}}$ \\
Total & 100 & $22(22 \%)^{\mathrm{a}}$ & $10(10 \%)^{\mathrm{b}}$ \\
\hline
\end{tabular}

* Cows with a history of abortion, reproductive problems and/or decreased milk production. ** Cows without a history of abortion, reproductive problems and/or decreased milk production. Within a row, the positive RBPT and iELISA results that do not have similar small letter superscripts ( ${ }^{\mathrm{a}}$ and $\left.{ }^{b}\right)$ vary from each other $(\mathrm{P}<0.05)$.

\section{PCR analysis}

Out of the 22 milk's DNA extracts of the RBPT-positive cows, 18 were shown to be positive for the Brucella genusspecific gene BCSP31 as indicated by amplification of the 223 bp DNA fragment (Table 3, Figure 3). These 18 milk's DNA extracts were also shown to be positive for the $B$. abortus-specific gene IS711 as indicated by amplification of the of the $113 \mathrm{bp}$ DNA fragment (Figure 4). However, they were negative for the B. melitensis and B. suis specific genes. The remaining 4 milk's DNA extracts were shown to be negative for Brucella genus-specific gene BCSP31, $B$. abortus, B. melitensis and B. suis specific genes.

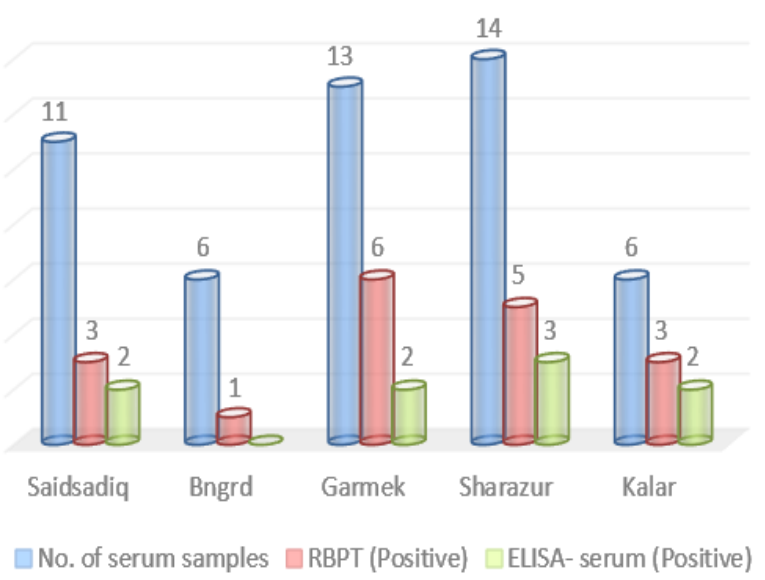

Figure 1: Serological detection of brucellosis by the RBPT and iELISA in cows of group one (cows with a history of abortion, reproductive problems and/or decreased milk production).

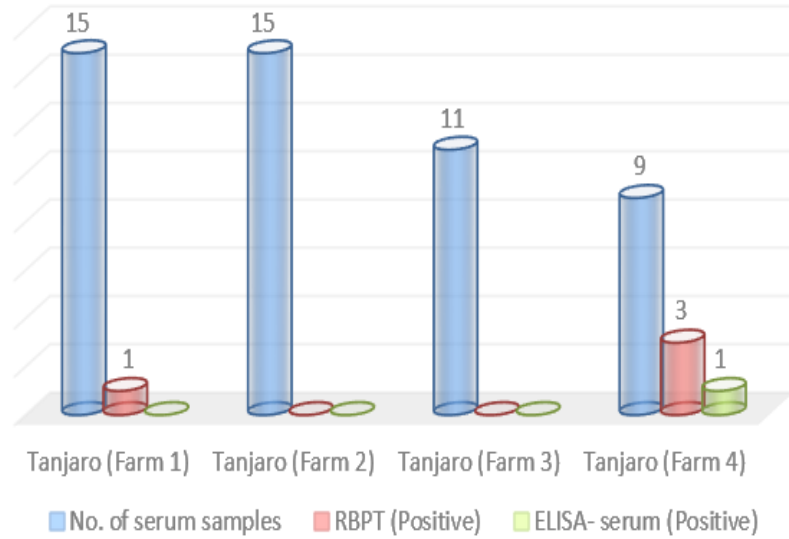

Figure 2: Serological detection of brucellosis by the RBPT and iELISA in cows of group two (cows without a history of abortion, reproductive problems and/or decreased milk production). 
Table 3: PCR results of the milk's DNA extracts of the RBPT-positive cows

\begin{tabular}{lcc}
\hline Animal groups & $\begin{array}{c}\text { No. of } \\
\text { seropositive cows } \\
\text { (by RBPT) }\end{array}$ & $\begin{array}{c}\text { No. of PCR } \\
\text { positive cows }\end{array}$ \\
\hline Group one cows * & $18^{\mathrm{a}}$ & $14^{\mathrm{b}}$ \\
Group two cows ** & $4^{\mathrm{a}}$ & $4^{\mathrm{a}}$ \\
Total & $22^{\mathrm{a}}$ & $18^{\mathrm{b}}$ \\
\hline
\end{tabular}

* Fifty cows with a history of abortion, reproductive problems and/or decreased milk production. ** Fifty cows without a history of abortion, reproductive problems and/or decreased milk production. Within a row, the RBPT and PCR results that do not have similar small letter superscripts $\left({ }^{\mathrm{a}}\right.$ and $\left.{ }^{\mathrm{b}}\right)$ vary from each other $(\mathrm{P}<0.05)$.

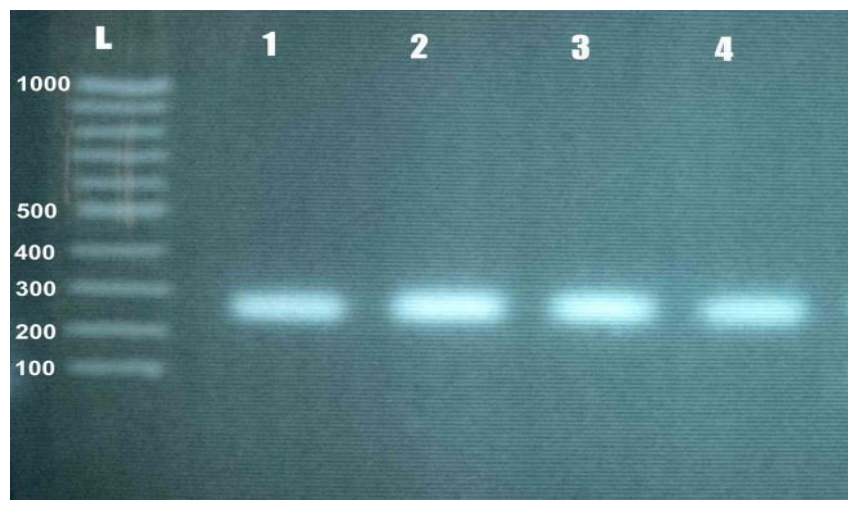

Figure 3: Agarose gel electrophoresis of the amplified milk's DNA extracts of the RBPT-positive cows. L: 100 bp DNA Ladder, Lane 1: Positive control (B. abortus S19), Lanes 24: Milk's DNA extracts positive for the 223 bp DNA fragment of the Brucella genus-specific gene BCSP31.

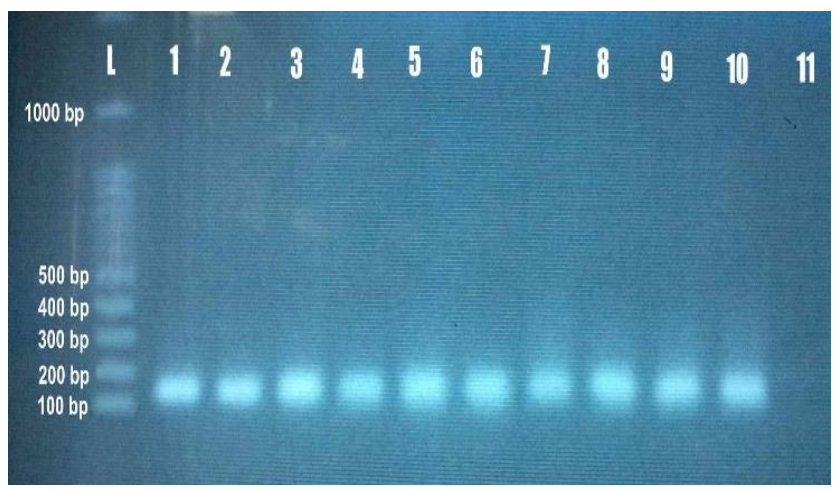

Figure 4: Agarose gel electrophoresis of the amplified milk's DNA extracts of the RBPT-positive cows. L: 100 bp DNA Ladder, Lanes 1-9: Milk's DNA extracts positive for the 113 bp DNA fragment of the B. abortus-specific gene IS711, Lane 10: positive control (B. abortus S19), Lane 11: negative control.

\section{Discussion}

The current study showed a lower sensitivity of the iELISA compared to the RBPT in detection of the seropositive cows is in agreement with the results of Zakaria (15) and it indicates that the RBPT could be more sensitive rather than more specific in comparison with the iELISA in serological detection of brucellosis (16) due to the higher possibility of false positive reaction that might take place as a result of concurrent or previous infection with some other gram-negative bacteria particularly Yersinia enterocolitica serotype O: 9; thus, it has been recommended that the serum samples that reveal a positive result by the RBPT should be certified by more specific tests (17). In addition, the higher sensitivity of RBPT compared to iELISA in the present study can be attributed to the fact that the RBPT is a screening test which qualitatively detects both the IgM and IgG antibodies whereas the iELISA used in this study is a quantitative test that specifically detects only IgG antibodies (18). Moreover, according to instructions of the iELISA kit manufacturer (IDEXX, USA), all of the serum samples were diluted to 1:100 resulting in a decrease in the concentration or quantity of antibodies in comparison with the RBPT procedure applied in this study which was performed without serum dilution.

The application of PCR-based assays for detection and identification of Brucella species has been increased due to their accuracy, sensitivity, speed and ability to work with DNA rather than the highly infectious live cultures (7). The PCR assays were proved to be a good means for rapid and accurate diagnosis especially for slow growing bacteria like Brucella (18), Mycobacterium paratuberculosis (19), Shigella (20), lactic acid bacteria (21), and the most proteolytic active bacteria as Aeromonas hydrophila (22) and to detect Brucella DNA from clinical specimens, thus the DNA detection of pathogenic organisms have been rendered biologically safe and reducing the risk of infection of laboratory workers (14).

In the present study, the PCR assay was used for detection of Brucella genus in the milk samples of the RBPT positive cows using the Brucella genus-specific primer pair B4/B5 which amplify the BCSP31 gene 223bp that codes for a 31-kDa immunogenic outer membrane protein conserved among all Brucella species. The BCSP 31 gene based PCR assay is a highly sensitive and specific means widely used for detection of brucellosis in clinical samples (12). The PCR assay revealed that 18 out of the 22 milk samples of the RBPT positive cows were positive for the genus Brucella, whereas the remaining 4 milk samples were negative. This finding, which is in agreement with Moussa et al. (7) and ElDiasty et al. (23), can be attributed to the possibility of the periodic shedding of Brucella organisms in the milk of the infected animals and to the probability of false negative results that may encountered in the PCR assays particularly in the chronic cases due to presence of a number of Brucella 
organisms below the threshold of detection by the specific primers (24). In addition, there are several other factors that can result in false negative results in the PCR assays such as degradation of target DNA in the sample, milk components such as $\mathrm{Ca}^{2+}$, proteinase, fats, polysaccharides, and milk proteins which may act as inhibitors for the nucleic acid amplification by shielding DNA from polymerase access and/or presence of polymerase inhibitors such as hemoglobin, heparin, phenol, EDTA, and sodium dodecyl sulfate (25).

PCR assays based on three pairs of species-specific primers for B. abortus, B. melitensis and B. suis were also performed in the present study in order to identify the species of Brucella in milk samples of the RBPT positive cows. The results of these PCR assays revealed B. abortus as the only Brucella species identified in milk samples of the seropositive cows. This finding can be ascribed to the fact that the cows included in this study were raised separately from sheep and goat flocks. In addition, vaccination programs using the $B$. melitensis Rev-1 strain have been applied on sheep and goat flocks. These measures could result in restriction of $B$. melitensis transmission from sheep and goats to cattle and decrease the probability of pastures contamination and spread the disease to the other animal herds or areas $(8,18)$.

\section{Conclusion}

Serological tests such as RBPT and iELISA followed by PCR assay for milk samples of the seropositive cows could provide more specific detection than performing either test alone and could be more useful for rapid screening of brucellosis in dairy cows.

\section{Acknowledgments}

We are grateful to the Directorate of Veterinary Hospital in Al-Sulaimaniyah governorate, Iraq for providing the laboratory facilities to perform the iELISA and PCR assays. We also thank Dr. Peshnyar Atta for providing the technical assistance and facilities to achieve the PCR assay.

\section{Conflict of interest}

The authors declare that there is no conflict of interest.

\section{References}

1. Kaltungo BY, Saidu SNA, Musa IW, Baba AY. Brucellosis: a neglected zoonosis. Int Res J Microbiol. 2014;4(12):1551-1574. DOI: 10.9734/BMRJ/2014/11061

2. Al-Mashhadany DA. The significance of milk ring test for identifying brucella antibodies in cows and buffaloes' raw milk at Erbil governorate, Iraq. Iraqi J Vet Sci. 2019;33(2):395-400. DOI: $\underline{10.33899 / \text { ijvs.2019.163085 }}$
3. Meng K, Abdurahman X. Study of the brucellosis transmission with multi-stage. Commun Math Biol Neurosci. 2018; 20:1-14. DOI: $10.28919 / \mathrm{cmbn} / 3796$

4. Foster JT, Okinaka RT, Svensson R, Shaw K, De BK, Robison RA, Probert WS, Kenefic LJ, Brown WD, Keim P. Real-time PCR assays of single-nucleotide polymorphisms defining the major Brucella clades. J Clin Microbiol. 2008;46:296-301. DOI: 10.1128/JCM.0149607

5. Foster G, Osterman BS, Godfroid J, Jacques I, Cloeckaert A. Brucella ceti sp. nov. and Brucella pinnipedialis sp. nov. For Brucella strains with cetaceans and seals as their preferred hosts. Int J Syst Evol Microbiol. 2007;57(11):2688-93. DOI: 10.1099/ijs.0.65269-0

6. Ahanger SA, Shah MM, Rather TA, Rather MA, Amani I, Magray SN, Sakina A, Razvi R, Bashir U, Gilkar UA. Seroprevalence of ovine brucellosis in Kashmir valley, a prospective and retrospective study. J E Zool Stud. 2020;8(4):1138-1140. DOI: 10.22271/j.ento

7. Moussa IM, Omnia ME, Amin AS, Ashgan MH, Selim SA. Evaluation of the currently used polymerase chain reaction assays for molecular detection of Brucella species. Afr J Microbiol Res. 2011;5(12):1511520. DOI: 10.5897/AJMR11.054

8. International Office of Epizootics. Biological Standards Commission, International Office of Epizootics. International Committee. Manual of diagnostic tests and vaccines for terrestrial animals: Mammals, birds and bees. Office international des épizooties; 2018. [available at]

9. Baily GC, Kraahn JB, Drasar BS, Stokeer NG. Detection of Brucella melitensis and Brucella abortus by DNA amplification. Am J Trop Med Hyg. 1992;95:271-275. DOI: 10.1016/j.vetmic.2005.06.007

10. Bricker BJ, Halling SM. Differentiation of Brucella abortus biovar.1, 2 and 4 Brucella melitensis, Brucella ovis and Brucella suis biovar.1 by PCR. J Clin Microbiol.1994;32:2660-2666. DOI: 10.1128/JCM.32.11.2660-2666.1994

11. Shahrokhabadi R, Rahimi E, Mommtaz H, Poursahebi R, Doostmohamadi S. The Efficacy of Multiplex PCR in Comparison with Agglutination and ELISA in Diagnosis of Human Brucellosis. Zahedan J Res Med Sci. 2014;16 (4):24-28. DOI: 10.22207/JPAM.11.2.05

12. Handel IG. Statistics for veterinary and animal science. $3^{\text {rd }}$ ed. New York: Wily Blackwell; 2013. 12-78 p. DOI: 10.1136/vr.f7415

13. Preacher KJ. Calculation for the chi-square test: An interactive calculation tool for chi-square tests of goodness of fit and independence [Computer software].

14. Pan W. Approximate confidence intervals for one proportion and difference of two proportions. Comput Stat Data Anal. 2002;40(1):143-157. DOI: 10.1016/S0167-9473(01)00107-4

15. Zakaria AM. Comparative Assessment of sensitivity and specificity of rose bengal test and modified in-house ELISA by using IS711 TaqMan real time PCR assay as a gold standard for the diagnosis of bovine brucellosis. Biomed Pharmacol J. 2018;11(2):951-957. DOI: $10.13005 / \mathrm{bpj} / 1453$

16. Saxena HM, Chothe S, Kaur P. Simple solutions to false results with plate/slide agglutination tests in diagnosis of infectious diseases of man and animals. Methods X. 2015;2:345-352. DOI: 10.1016/j.mex.2015.08.001

17. Muñoz PM, Marín CM, Monreal D, Gonzalez D, Garin-Bastuji B, Diaz R, Mainar-Jaime RC, Moriyon I, Blasco JM. Efficacy of several serological tests and antigens for diagnosis of bovine brucellosis in the presence of false-positive serological results due to Yersinia enterocolitica O:9. Clin Diagn Lab Immunol. 2005;12(1):141-151. DOI: $10.1128 / C D L I .12 .1 .141-151.2005$

18. Rahman MS, Sarker MAS, Rahman AA, Sarker RR, Melzer F, Sprague $\mathrm{LD}$, Neubauer $\mathrm{H}$. The prevalence of Brucella abortus DNA in seropositive bovine sera in Bangladesh. Afr $\mathrm{J}$ Microbiol Res. 2014;8(48):3856-3860. DOI: 10.5897/AJMR2014.6031

19. Ahmed IM, Al-Sanjary RA, Al-Khazaly HH. Detection of Mycobacterium paratuberculosis in raw cow's milk using polymerase chain reaction (PCR) technique. Iraqi J Vet Sci. 2020;34 (1):83-86. DOI: 10.33899 /ijvs.2019.125556.1075

20. Soulieman N, Al-Mariri A, Al-Atrash F. Detection of Shigella in raw bovine milk by polymerase chain reaction. Iraqi J Vet Sci. 2020;34(1):9-16. DOI: 10.33899/ijvs.2019.125758.1146 
21. Saeed ZK, Abbas BA, Othman RM. Molecular identification and phylogenetic analysis of lactic acid bacteria isolated from goat raw $\begin{array}{lllll}\text { milk. Iraqi J Vet Sci. 2020;34 } & \text { (2):259-263. DOI: }\end{array}$ 10.33899/ijvs.2019.125896.1176

22. Zubairi RB. Genetic detection to Aeromonas hydrophila proteolytic activity in milk samples (cows, buffaloes and goats) in Basra $\begin{array}{llllll}\text { governorate. } & \text { Iraqi J Vet } & \text { Sci. } & 2020 ; 34 & \text { (2): } & 253-258 .\end{array}$ DOI: $10.33899 /$ ijvs.2019.125888.1174

23. El-Diasty MM, Ahmed HA, Sayour AE, El Hofy FI, Tahoun AB, Shafik SM. Seroprevalence of Brucella spp. in cattle, molecular characterization in milk, and the analysis of associated risk factors with seroprevalence in humans, Egypt. Vector Borne Zoonotic Dis. 2016;16(12):758-764. DOI: $10.1089 /$ vbz.2016

24. Hinić V, Brodard I, Thomann A, Cvetnić Z, Makaya PV, Frey J, Abril C. Novel identification and differentiation of Brucella melitensis, $B$. abortus, $B$. suis, B. ovis, B. canis, and B. neotomae suitable for both conventional and real-time PCR systems. J Microbiol Methods. 2008;75(2):375-378. DOI: $10.1016 /$ j.mimet.2008.07.002

25. Wilson IG. Inhibition and facilitation of nucleic acid amplification. Appl Environ Microbiol. 1997;63:3741-3751. DOI: $\underline{\text { 10.1128/AEM.63.10.3741-3751.1997 }}$

\section{التحري المصلي والجزيئي لاء البروسيلات في أبقار

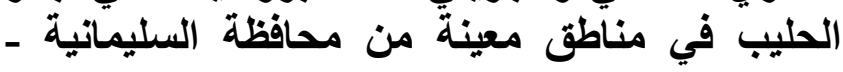 العراق}

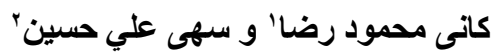

'مديرية المستشفى البيطري في السليمانية، ` فرع العلوم الأساسية، كلية

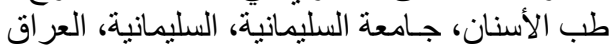

الخلاصة

كان الهُف من هذه الدراسة الكثف عن الأجسام المضادة لداء

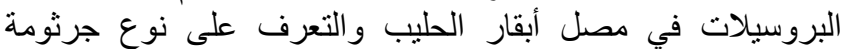

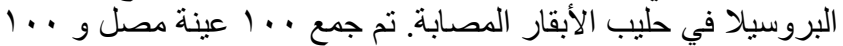

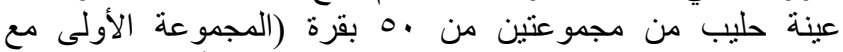
و المجموعة الثانية بدون تاريخ من المشاكل التناسلية أو انخفاض من إنها إنتاج

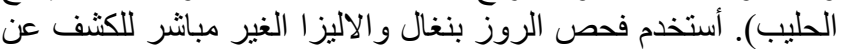

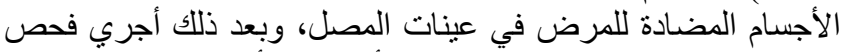

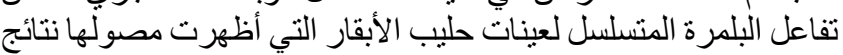

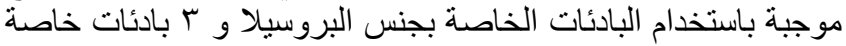

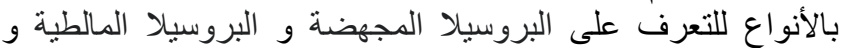

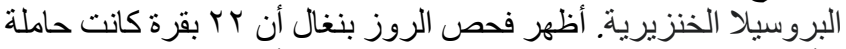

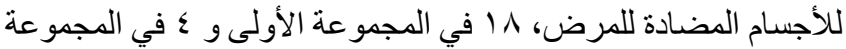

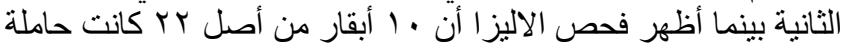

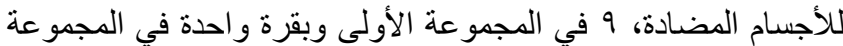

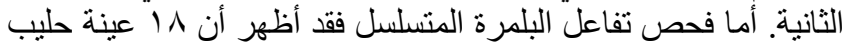
فقط كانت موجبة لجنس البروسيلا ولنوع البروسيلا المجهضة فئة فيما كانت جميع العينات سالبة لنوعي البروسيلا المالطية و البروسيلا الخنزية البروية البرية. دلت نتائج هذه الدراسة على أن داء البراء البروسيلات قد تم اكتشافه في الأبقار

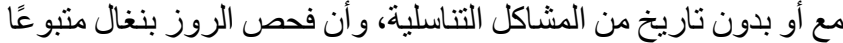
بفحص تفاعل البلمرة المتسلسل لعينات حليب الأبقار إيجابية المصل

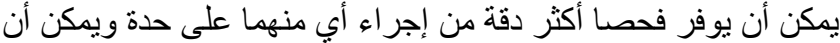
يكون أكثر فائدة في التحري السريع عن مرض البروسئ من إهيلا في أبقار الحليب. 